\title{
Keanekaragaman dan Kelimpahan Kupu-Kupu (Lepidoptera : Rhopalocera) di Cagar Alam Bantarbolang, Jawa Tengah
}

\author{
Ulfah Nuraini*, Imam Widhiono, Edy Riwidiharso \\ Faklutas Biologi Universitas Jenderal Soedirman \\ Jalan dr. Soeparno 63 Purwokerto 53122 \\ Email : nurainiulfah17@gmail.com
}

Rekam Jejak Artikel:

Diterima : 29/08/2019

Disetujui : 07/04/2020

\begin{abstract}
Butterflies are insects that are included in the Order of Lepidoptera, meaning insects that are almost completely covered by scales that give the color and color of the wings of a butterfly. The diversity and abundance of butterflies is influenced by environmental factors such as the intensity of sunlight, temperature, and humidity. This study aims to determine the diversity and abundance of butterflies in Bantarbolang Nature Reserve, Central Java. Data can be analyzed using the index diversity of the Shannon-Wiener diversity index, the Shannon-Evenners evenness index, and the dominance index. The results of the research that has been conducted show that 359 individuals were found in 6 families. The highest diversity is at a distance of $0 \mathrm{~m}$ $\left(\mathrm{H}^{\prime}=2.760\right.$; E: 0.752). The highest abundance at a distance of $0 \mathrm{~m}$ with the number of individuals is 192 . The highest diversity at a distance of $0 \mathrm{~m}$ at the edge of the forest, while the lowest diversity at a distance of $150 \mathrm{~m}$ in the forest. The diversity of butterflies is dominated by H. glaucippe from the Piridae family of 64 individuals. Environmental factors that most influence the diversity and abundance of butterflies are the intensity of sunlight.

Key Words: Butterfly, Diversity, Abundance, Bantarbolang Nature Reserve
\end{abstract}

\begin{abstract}
Abstrak
Kupu-kupu adalah serangga yang termasuk dalam Ordo Lepidoptera, artinya serangga yang hampir seluruh permukaan tubuhnya tertutupi oleh lembaran-lembaran sisik yang memberi corak dan warna sayap kupu-kupu. Keanekaragaman dan Kelimpahan kupu-kupu di pengaruhi oleh faktor lingkungan seperti intensitas cahaya matahari, temperatur, dan kelembapan. Penelitian ini bertujuan untuk mengetahui keanekaragaman dan kelimpahan kupu-kupu di Cagar Alam Bantarbolang, Jawa Tengah. Data yang di dapat di analisis menggunakan indeks keanekaragaman indeks keanekaragaman Shannon-Wiener, indeks kemerataan ShannonEvenners, dan Indeks dominansi. Hasil penelitian yang telah dilakukan menunjukkan bahwa ditemukan 359 individu dalam 6 familia. Keanekaragaman tertinggi yaitu pada jarak $0 \mathrm{~m}\left(\mathrm{H}^{\prime}=\right.$ 2.760; E: 0,752). Kelimpahan tertinggi pada jarak $0 \mathrm{~m}$ dengan jumlah individu sebanyak 192. Keanekaragaman tertinggi pada jarak $0 \mathrm{~m}$ di tepi hutan, sedangkan keragaman terrendah pada jarak $150 \mathrm{~m}$ di dalam hutan. Keanekaragaman kupu-kupu didominasi oleh H. glaucippe dari famili Piridae sebanyak 64 individu. Faktor lingkungan yang paling mempengaruhi keanekaragaman dan kelimpahan kupu-kupu adalah intensitas cahaya matahari.

Kata kunci: Kupu-kupu, Keanekaragaman, Kelimpahan, Cagar Alam Bantarbolang
\end{abstract}

\section{PENDAHULUAN}

Cagar alam Bantarbolang berada di Desa Kebon Gede, Kecamatan Bantarbolang, Kabupaten Pemalang. Kawasan ini ditetapkan sebagai kawasan Cagar alam berdasarkan Surat Hoofd Inspecteur No. 2980, tanggal 19 Mei 1930 diperkuat dengan SK Penunjukan Menteri Kehutanan No. SK.359/Menhut-II/2004 tanggal 1 Oktober 2004. Cagar Alam ini terletak pada ketinggian $100 \mathrm{~m}$ di atas permukaan laut dengan suhu harian antara $26^{\circ}-$ $28^{\circ} \mathrm{C}$, kelembaban udara minimum $77 \%$ dan maksimum $85 \%$ serta curah hujan rata-rata 3.000$4.000 \mathrm{~mm} / \mathrm{tahun}$. Kawasan konservasi ini terdapat beberapa jenis Insekta, salah satunya adalah Kupukupu. (BKSDA Jateng, 2004). Keanekaragaman hayati atau biodiversitas adalah semua kehidupan di atas bumi ini tumbuhan, hewan, jamur dan mikroorganisme serta berbagai materi genetik yang dikandungnya dan keanekaragaman sistem ekologi di mana mereka hidup. Keanekaraga-man hayati meliputi kelimpahan dan keanekaragaman genetik dari organisme yang berasal dari semua habitat, baik yang ada di darat, laut maupun sistem-sistem perairan lainnya. Keanekaragaman jenis kupu-kupu yang tinggi dan penyebaran kupu-kupu dalam suatu wilayah dipengaruhi oleh faktor habitat kupu-kupu yaitu faktor-faktor lingkungan yang sesuai dengan kebutuhan kupu-kupu di alam, suhu, kelembaban, dan curah hujan serta topografi dan vegetasi. Kelimpahan jenis adalah jumlah individu setiap jenis yang ditemukan pada setiap titik pengambilan sampel. Struktur komunitas kupu-kupu dapat digunakan untuk mengetahui tingkat kerusakan hutan, karena kupu-kupu menyukai tempat yang 
sejuk dan bersih, tidak tercemar insektisida, asap dan bau yang tidak sedap. Semakin tinggi keragaman spesies kupu-kupu di suatu tempat menandakan lingkungan tersebut masih baik (Dewi et al., 2016).

Kupu-kupu adalah serangga yang termasuk dalam Ordo Lepidoptera atau "serangga bersayap sisik", artinya serangga yang hampir seluruh permukaan tubuhnya tertutupi oleh lembaranlembaran sisik yang memberi corak dan warna sayap kupu-kupu. Kupu-kupu merupakan jenis serangga yang paling banyak dikenal dan sering dijumpai karena bentuk dan warnanya yang indah dan beragam, dan pada umumnya aktif di siang hari (diurnal). Kupu-kupu digolongkan ke dalam subordo Rhopalocera karena sifatnya yang diurnal (Fauziyah et al., 2017). Kupu-kupu meliputi famili Papilionidae, Pieridae, Nymphalidae, Satyridae, Hesperiidae dan Lycaenidae. Tubuh kupu-kupu mempunyai bagian-bagian yang sama dengan serangga yang lain. Kupu-kupu memiliki dinding tubuh yang disebut integumen, yang berfungsi sebagai kerangka luar (eksoskeleton). Tubuh kupukupu terbagi menjadi tiga bagian, yaitu kepala, thoraks, dan abdomen. Pada bagian kepala terdapat dua antena yang panjang yang di bagian ujungnya membesar. Antena ini berfungsi sebagai organ peraba dan perasa. Pada bagian kepala juga terdapat mata majemuk sepasang, dan probosis yang berfungsi sebagai penghisap cairan. Pada bagian thoraks terdapat dua pasang sayap yang menempel pada segmen kedua dan ketiga. Kupu-kupu memiliki karakteristik yang khusus pada sayap, yaitu sisik. Sisik ini mengandung pigmen melanin yang memberikan warna hitam dan coklat. Warna biru, hijau, merah, dan warna lainnya pada sayap, biasanya tidak dibentuk oleh pigmen tetapi dari struktur sisik pada sayap. Warna struktur ini merupakan hasil dari pantulan cahaya pada sisik yang saling bertumpukan oleh kristal fototonik alami. Bentuk, ukuran, warna, dan venasi sayap merupakan bagian paling penting dalam identifikasi kupu-kupu (Priyono \& Abdullah, 2013).

\section{MATERI DAN METODE}

Bahan yang digunakan dalam penelitian adalah kupu-kupu ordo Lepidoptera di Cagar Alam Bantarbolang. Alat yang digunakan dalam penelitian ini adalah jaring serangga, tali rafia, patok, gunting, kamera, termohygrometer, luxmeter, wadah sampel, buku identifikasi, dan alat tulis.Penelitian dilaksanakan bulan Februari sampai bulan Maret 2019 di Cagar Alam Bantarbolang, Pemalang, Jawa tengah. Secara geografis Cagar Alam Bantarbolang termasuk dalam wilayah Desa Kebon Gede, Kecamatan Bantarbolang, Kabupaten Pemalang.
Cagar alam ini terletak pada ketinggian $100 \mathrm{~m}$ di atas permukaan laut dengan keadaan topografi datar, jenis tanah latosol coklat kemerahan, mempunyai tipe iklim B, suhu harian antara $26^{\circ} \mathrm{C}-28^{\circ} \mathrm{C}$ di titik koordinat sekitar $7^{0} 019937,2$ " LS $109^{0} 254649,1$ ” BT.

Metode penelitian yang digunakan dalam penelitian ini adalah metode survey dan teknik pengambilan sampling scan sampling. Garis transek ditetapkan dengan panjang $200 \mathrm{~m}$ dan lebar $5 \mathrm{~m}$, kemudian dibuat empat kali ulangan transek berjalan. Pengambilan sampel kupu-kupu dilakukan pada pukul 08.00 - 12.00 WIB pada saat cuaca cerah.

Variabel pada penelitian ini terdiri atas variabel terikat dan variabel bebas. Variabel terikat yaitu kupu-kupu, sedangkan variabel bebas yaitu faktor lingkungan antara lain temperatur, kelembapan, dan intensitas cahaya. Parameter pada penelitian ini adalah jumlah spesies kupu-kupu dan jumlah individu tiap spesies kupu-kupu.

Data yang diperoleh dianalisis secara deskriptif. Data keanekaragaman dan kelimpahan kupu-kupu yang dihitung meliputi indeks keragaman Shannon Wienner (H'), indeks kemerataan Shannon-Evennnes (E) dan indeks dominansi Simpson (D) dengan software PAST sedangkan analisis kesamaan (similarity) pada jarak yang berbeda dianalisis menggunakan software Biodiversity Pro.

\section{Indeks Keanekaragaman Shannon-Wiener}

$$
\mathrm{H}^{\prime}=-\sum_{\mathrm{i}=1}^{\infty} \mathrm{p}_{\mathrm{i}}\left(\ln \mathrm{p}_{\mathrm{i}}\right)
$$

Keterangan:

$$
\begin{array}{ll}
\mathrm{Pi} & =\text { ni/N total } \\
\mathrm{H} & =\text { indeks keanekaragaman } \\
\mathrm{pi} & =\text { proporsi dari tiap spesies } \\
\mathrm{ni} & =\text { jumlah individu spesies } \mathrm{ke}-\mathrm{i} \\
\mathrm{i} & =\text { spesies } \mathrm{ke}-\mathrm{i} \\
\mathrm{N} & =\text { jumlah total spesies } \\
\mathrm{ln} & =\text { logaritma natural }
\end{array}
$$

Indeks Kemerataan Shannon-Evenners

$$
\mathrm{E}=\frac{H}{\ln S}
$$

Keterangan:

$$
\begin{array}{ll}
\mathrm{E} & =\text { indeks kemerataan Shannon-Evenners } \\
\mathrm{H} & =\text { indeks keanekaragaman Shannon-Wiener } \\
\mathrm{S} & =\text { jumlah spesies } \\
\mathrm{ln} & =\text { logaritma natural }
\end{array}
$$


Indeks Dominansi Simpson

$$
\mathrm{D}=\sum(\mathrm{pi})^{2}
$$

Keterangan:

$$
\text { pi }=\text { proporsi dari tiap spesies }
$$

\section{HASIL DAN PEMBAHASAN}

Kekayaan Spesies Semut (Hymenoptera: Formicidae) di Cagar Alam Bantarbolang dengan Jarak Berbeda

Berdasarkan penelitian yang telah dilakukan menunjukkan bahwa di Cagar Alam Bantarbolang didapatkan kupu-kupu sebanyak 24 spesies yang termasuk ke dalam 6 familia antara lain Papilionidae, Hesperiidae, Satyridae, Nympalidae, Pieridae dan Lycaenidae. Famili Papilionidae ditemukan 4 spesies, famili Hesperiidae ditemukan 5 spesies, famili Satyridae ditemukan 1 spesies, famili Nymphalidae ditemukan 9 spesies, famili Pieridae ditemukan 4 spesies dan famili Lycaenidae ditemukan 1 spesies. Jumlah spesies kupu-kupu pada jarak $0 \mathrm{~m}, 50 \mathrm{~m}, 100 \mathrm{~m}, 150 \mathrm{~m}$, dan $200 \mathrm{~m}$ masing-masing adalah 20,13, 12, 11, dan 13 spesies (Tabel 1.).

Tabel 1. Jumlah Spesies Dan Individu Semut (Hymenoptera: Formicidae) di Cagar Alam Bantarbolang pada

\begin{tabular}{|c|c|c|c|c|c|c|}
\hline \multirow{2}{*}{ Familia } & \multirow{2}{*}{ Nama Spesies } & \multicolumn{5}{|c|}{ Jumlah Individu (rata-rata \pm standar deviasi) } \\
\hline & & $0 \mathrm{~m}$ & $50 \mathrm{~m}$ & $100 \mathrm{~m}$ & $150 \mathrm{~m}$ & $200 \mathrm{~m}$ \\
\hline \multirow{4}{*}{ Papilionidae } & Papilio polytes javanus & $1.50 \pm 1.29$ & $1.25 \pm 0.50$ & $0.50 \pm 0.58$ & $0.25 \pm 0.50$ & 0 \\
\hline & Graphium Agamemnon & $2.50 \pm 1.29$ & $1.50 \pm 1.91$ & $0.75 \pm 0.96$ & $0.25 \pm 0.50$ & $1.25 \pm 1.50$ \\
\hline & Troides helena & $1.25 \pm 1.50$ & $0.50 \pm 1$ & 0 & 0 & 0 \\
\hline & Papilio coon coon & 0 & 0 & $0.75 \pm 0.96$ & 0 & 0 \\
\hline \multirow{5}{*}{ Hesperiidae } & Oriens paragola & $0.50 \pm 0.58$ & $0.25 \pm 0.50$ & 0 & 0 & 0 \\
\hline & Potanthus omaha & $2.25 \pm 1.89$ & $0.25 \pm 0.50$ & 0 & $0.25 \pm 0.50$ & 0 \\
\hline & Pelopidas conjuncta & 0 & 0 & $0.50 \pm 0.58$ & 0 & 0 \\
\hline & Notocrypta paralysos & 0 & 0 & 0 & 0 & $1.25 \pm 1.50$ \\
\hline & Udaspes folus & 0 & 0 & 0 & 0 & $0.25 \pm 0.50$ \\
\hline Satyridae & Ypthima nigricans & $3 \pm 1.83$ & 0 & $1.25 \pm 0.96$ & 0 & 0 \\
\hline \multirow{9}{*}{ Nymphalidae } & Elymnias hypermnestra & $5.25 \pm 2.87$ & $0.50 \pm 0.58$ & 0 & $0.75 \pm 1.50$ & $2.75 \pm 2.22$ \\
\hline & Junonia iphtima & $5.50 \pm 2.38$ & $1.25 \pm 0.96$ & $0.25 \pm 0.50$ & 0 & 0 \\
\hline & Junonia hedonia & $2.50 \pm 1.29$ & $2.50 \pm 1.29$ & $1 \pm 1.15$ & $0.25 \pm 0.50$ & $2 \pm 1.83$ \\
\hline & Euploea tulliolus & $0.25 \pm 0.50$ & $0.25 \pm 0.50$ & 0 & $0.25 \pm 0.50$ & 0 \\
\hline & Euploea mulciber & $1.75 \pm 2.06$ & 0 & 0 & 0 & 0 \\
\hline & Dolescalia bisaltisae & $1 \pm 1.15$ & 0 & $0.25 \pm 0.50$ & 0 & $0.25 \pm 0.50$ \\
\hline & Moduza procris & $1.50 \pm 1.73$ & 0 & 0 & 0 & 0 \\
\hline & Hipolymnas bolina & $1.50 \pm 1$ & $0.25 \pm 0.50$ & $1.25 \pm 1.26$ & $0.25 \pm 0.50$ & $1.25 \pm 0.96$ \\
\hline & Neptis hylas & $0.75 \pm 0.96$ & $0.75 \pm 0.96$ & 0 & $0.75 \pm 0.96$ & 0 \\
\hline \multirow{4}{*}{ Pieridae } & Hebomoia glaucippe & $7.75 \pm 2.06$ & $3.5 \pm 1.29$ & $1.25 \pm 0.96$ & $0.50 \pm 1$ & $3 \pm 2.45$ \\
\hline & Appias libythea & $2.25 \pm 2.63$ & 0 & 0 & $0.25 \pm 0.50$ & $0.25 \pm 0.50$ \\
\hline & Eurema hecabe & $4.75 \pm 4.50$ & $0.75 \pm 0.96$ & $1.25 \pm 0.50$ & $0.50 \pm 0.58$ & $1.75 \pm 1.71$ \\
\hline & Leptosia nina & $2 \pm 2.83$ & 0 & 0 & 0 & $0.25 \pm 0.50$ \\
\hline Lycaenidae & Loxura atymnus fuconius & $0.25 \pm 0.50$ & 0 & 0 & 0 & $0.75 \pm 1.50$ \\
\hline
\end{tabular}
Tiap Jarak

Pada tabel 1 menunjukkan bahwa jumlah ratarata individu pada jarak $0 \mathrm{~m}(47,5), 50 \mathrm{~m}(13,5), 100$ m (9), $150 \mathrm{~m}(4,25)$ serta $200 \mathrm{~m}$ (15). Rata-rata individu paling banyak yaitu pada jarak $0 \mathrm{~m}$ dan paling sedikit pada jarak $150 \mathrm{~m}$. Famili Papilionidae ditemukan sebanyak 47 individu dengan presentase sebesar $13 \%$, Hesperiidae ditemukan sebanyak 22 individu dengan presentase sebesar $6 \%$, Satyridae ditemukan sebanyak 17 individu dengan presentase sebesar 5\%, Nymphalidae ditemukan sebanyak 149 individu dengan presentase sebesar $42 \%$, Pieridae ditemukan sebanyak 120 individu dengan presentase sebesar 33\% dan Lycaenidae ditemukan sebanyak 4 individu dengan presentase sebesar $1 \%$. Jumlah total individu sebanyak 359 individu kupu-kupu dari ke-6 familia tersebut yang ditemukan di Cagar Alam Bantarbolang dari jarak 0 meter sampai 200 meter (Gambar 1.). 


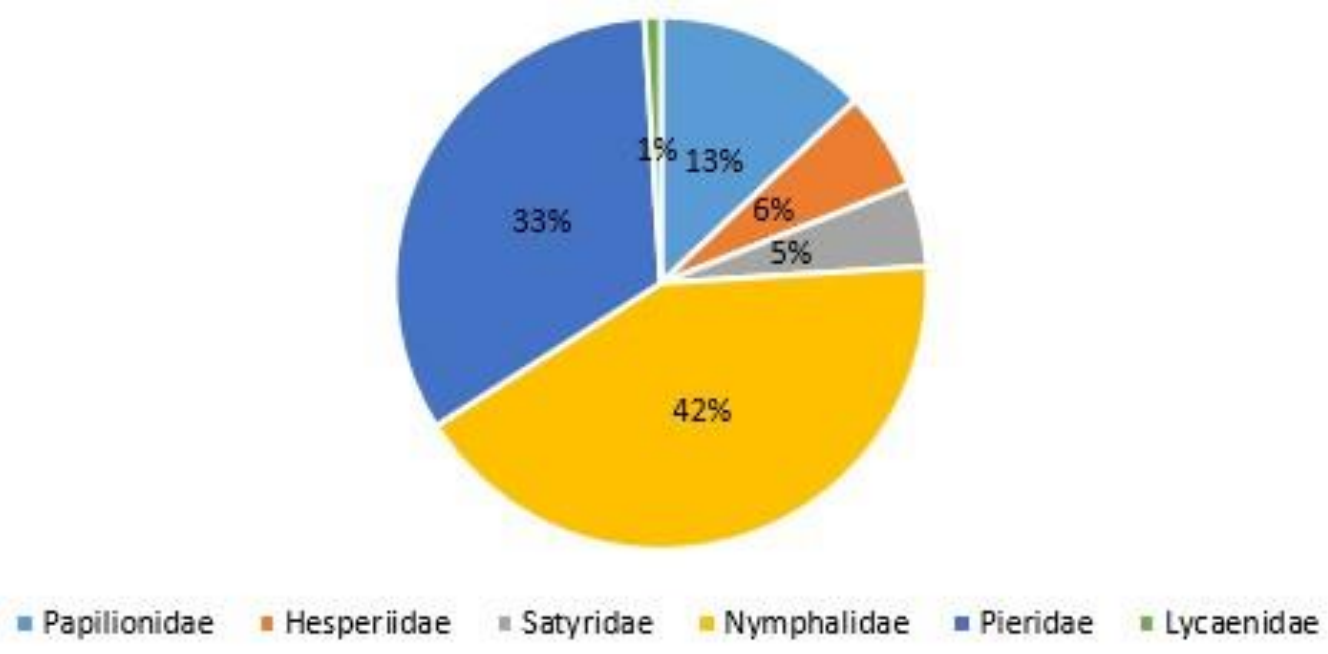

Gambar 1. Persentase Proporsi Familia Kupu-kupu di Cagar Alam Bantarbolang.

Nymphalidae merupakan famili yang individu terbanyak dimiliki yaitu sebanyak $42 \% \quad(149$ individu) dari total keseluruhan kupu-kupu yang ditemukan. Hal ini sesuai dengan Priyono \& Abdullah (2013) yang menyatakan bahwa besarnya proporsi famili Nymphalidae baik dari jenis maupun individu disebabkan karena Nymphalidae mempunyai tumbuhan inang lebih dari satu. Nymphalidae cenderung bersifat polifag (mempunyai jenis makanan lebih dari satu macam). Sifat polifag memungkinkan Nymphalidae tetap dapat memenuhi kebutuhannya akan tumbuhan inang meskipun tumbuhan inang utamanya tidak tersedia. Kondisi inilah yang menyebabkan Nymphalidae dapat dijumpai dalam jumlah jenis dan individu yang cukup besar di Cagar Alam Bantarbolang. Nymphalidae merupakan famili yang memiliki kelimpahan tertinggi yang ditemukan pada lokasi penelitian. Hal ini disebabkan karena adanya kemampuan beradaptasi dengan kondisi lingkungan, sehingga spesies dari famili tersebut dapat ditemukan pada setiap lokasi penelitian. Faktor lain juga disebabkan karena Nymhalidae merupakan kupu-kupu yang mempunyai anggota yang paling besar dan penyebaran luas dibandingkan dengan famili lainnya. Keberadaan Nymphalidae dalam jumlah besar juga dipengaruhi oleh tumbuhan sebagai sumber pakan (Koneri \& Saroyo, 2011). Famili yang paling sedikit ditemukan adalah Lycanidae dengan jumlah $1 \%$ (4 individu). Menurut Rahayuningsih et al. (2012) Faktor seperti cepatnya kemampuan terbang Lycanidae yang memungkinkan sedikitnya spesies yang terlihat pada saat penelitian. Famili Lycaenidae kebanyakan berukuran kecil kurang lebih $15 \mathrm{~mm}$, berwarna cemerlang, memiliki kemampuan terbang yang cepat dan menyukai tempat yang teduh. Ukuran tubuhnya yang relatif kecil diduga mempengaruhi kemampuan terbang yang rendah dan daerah jelajah yang sempit. Keanekaragaman kupu-kupu di suatu tempat berbeda dengan tempat yang lain, karena keberadaan kupu-kupu di suatu habitat sangat erat kaitannya dengan faktor lingkungan seperti temperatur, kelembapan dan intensitas cahaya. Data faktor lingkungan disajikan pada Tabel 2.

Tabel 2. Data Nilai Indeks Keragaman Shannon (H') berdasarkan Jarak dari Tepi Hutan dan Faktor Lingkungan di Cagar Alam Bantarbolang.

\begin{tabular}{ccccc}
\hline Jarak & Indek keragaman $\left(\mathrm{H}^{\prime}\right)$ & \multicolumn{3}{c}{ Faktor Lingkungan } \\
\cline { 3 - 5 } & & Temperatur $\left({ }^{\circ} \mathrm{C}\right)$ & Kelembaban $(\%)$ & $\begin{array}{c}\text { Int. Cahaya } \\
(\text { Lux })\end{array}$ \\
\hline 0 & 2.760 & 31 & 70 & 12.000 \\
50 & 2.208 & 29 & 71 & 10.000 \\
100 & 2.305 & 28 & 73 & 8.200 \\
150 & 2.282 & 28 & 74 & 7.900 \\
200 & 2.293 & 27 & 77 & 5.500 \\
\hline
\end{tabular}


Temperatur dan intensitas cahaya paling tinggi pada jarak $0 \mathrm{~m}\left(31^{\circ} \mathrm{C} ; 12000\right.$ lux $)$ dan paling rendah pada jarak $200 \mathrm{~m}\left(27^{\circ} \mathrm{C}\right.$; 5500 lux $)$. Kelembapan tertinggi pada jarak pada jarak $200 \mathrm{~m}(77 \%)$ dan terendah pada jarak $0 \mathrm{~m}(70 \%)$. Temperatur akan sangat mempengaruhi aktivitas kupu-kupu, penyebaran, pertumbuhan dan perkembangbiakan kupu-kupu. Kupu-kupu merupakan hewan dengan sayap bersisik (Lepidoptera) yang aktif pada siang hari saat intensitas cahaya tinggi. Kupu-kupu membutuhkan intensitas cahaya ma-tahari yang tinggi karena kupu-kupu menggu-nakan panas matahari untuk membantu terbang. Ketika cuaca dalam keadaan gelap atau hujan, kupu-kupu akan bersembunyi di balik daun. Cahaya sangat diperlukan oleh kupu-kupu karena kupu-kupu berdarah dingin (poikiloterm). Cahaya akan memberikan energi panas sehingga menaikkan suhu tubuh dan metabolisme menjadi lebih cepat, pada larva kupu-kupu peningkatan suhu tubuh akan mempercepat perkembangan larva kupu-kupu (Rahayuningsih et al. 2012). Berdasarkan hasil pengukuran faktor lingkungan didapat bahwa temperatur berbanding terbalik dengan kelembaban. Hal ini sesuai dengan Febrita et al. (2014) bahwa tinggi rendahnya nilai kelembaban udara pada suatu daerah dipengaruhi oleh temperatur udara pada daerah tersebut, dimana temperatur berbanding terbalik dengan kelembaban. Semakin tinggi suhu lingkungan maka kelembabannya akan semakin rendah. Untuk dapat beraktifitas optimal umumnya kelembaban udara lingkungan kupu-kupu berkisar antara $60-75 \%$.

\section{Jumlah Individu Kupu-kupu di Cagar Alam Bantarbolang}

Jumlah individu terbanyak ditemukan di jarak 0 meter (192 individu) dan paling sedikit ditemukan di titik 150 meter (17 individu). Jumlah individu cenderung menurun ke arah interior hutan. Namun, jumlah individu mengalami kenaikan pada titik 200 meter (Gambar 2). Perbedaan tersebut merupakan respon spesies kupu-kupu terhadap efek tepi sehingga dapat dikatakan bahwa tepi hutan mempengaruhi kelimpahan kupu-kupu.

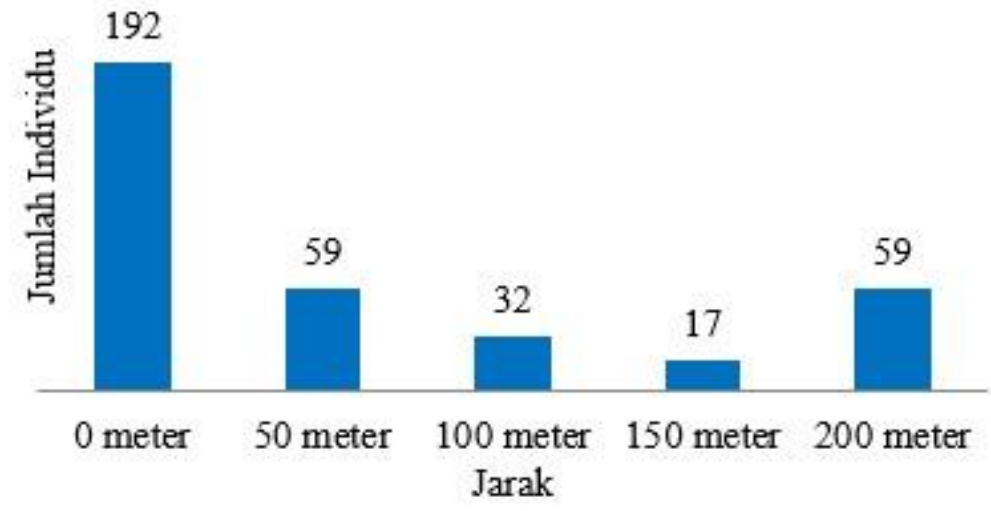

Gambar 2. Kelimpahan Individu Kupu-kupu pada Jarak yang Berbeda

Spesies yang paling banyak jumlah individunya yaitu $H$. glaucippe dari famili Piridae sebanyak 64 individu. Namun spesies ini termasuk ke dalam kategori jarang karena kurang dari 100 individu. Pieridae merupakan spesies yang banyak tersebar di daerah tropis, sebagaimana dinyatakan oleh Fauziyah et al. (2017) bahwa Pieridae banyak tersebar di daerah dataran rendah dan hutan hujan tropis. familia Piridae paling banyak ditemukan karena beberapa spesies biasanya turun ke tanah di habitat terbuka. Spesies yang paling sedikit ditemukan (hanya 1 individu dari keseluruhan jarak) antara lain dari familia Papilionidae yaitu $P$. coon coon, dari familia Hespiriidae yaitu $U$. folus. Famili Hesperiidae tidak banyak ditemukan diduga karena warnanya buram dan gelap dan aktifnya lebih banyak dalam semak, Famili Hesperidae dikenal sebagai kupu-kupu primitif dan mirip dengan kupukupu malam (moth) karena warna dari kupu-kupu ini buram dan gelap. Kupu-kupu Papilionidae sebagian besar merupakan jenis yang berukuran besar dengan pola warna yang indah. Kedua pasang sayapnya mempunyai garis-garis (gurat-gurat) membentuk sel tertutup. Pada beberapa jenis pasang sayap belakangnya memanjang membentuk bangunan mirip ekor. Beberapa jenis terbang lambat mirip burung layang-layang. Oleh karena itu sering disebut dengan kupu-kupu sayap burung birdwing atau swallow tails (Dendang, 2009).

Pengelompokkan kategori spesies dibagi menjadi tiga, yaitu: Rare species, Jarang dan Melimpah. Rare spesies (jumlah individu ditemukan kurang dari 10), spesies jarang (jumlah individu ditemukan lebih dari 10 dan kurang dari 100 individu), dan spesies melimpah (jumlah individu ditemukan lebih dari 100 individu), maka didapatkan sebanyak 14 spesies yang termasuk kategori rare species dan sebanyak 11 spesies termasuk kategori spesies jarang. Sedangkan spesies berkategori melimpah tidak ditemukan (Tabel 3). 
Tabel 3. Pengelompokkan Kategori Spesies

\begin{tabular}{cl}
\hline Katagori & Spesies \\
\hline Rare spesies & T. Helena, P.coon coon, O. Paragola, P. Conjuncta, N. paralysos, U. Folus, \\
& E.tulliolus, E.mulciber, E. Climena, D.bisaltisae, M.procris, L.nina, L.atymnus \\
& fuconius, N.hylas \\
Jarang & P.polytes javanus, G.agamemnon, P.omaha, Y.nigricans, E.hypermnestra, \\
& J.iphtima, J.hedonia, H.glaucippe, A.libythea dan H.bolina, E.hecabe \\
Melimpah & -
\end{tabular}

\section{Keragaman Kupu-kupu di Cagar Alam Bantarbolang}

Indeks keragaman Shannon (H') dengan indeks kemerataan Eveness (E) kupu-kupu berbedabeda pada setiap jarak di hutan. Indeks keragaman Shannon tertinggi pada jarak 0 meter $\left(H^{\prime}=2,760\right)$ sedangkan indeks kemerataan Eveness tertinggi pada jarak 150 meter $(E=0,891)$. Indeks keragaman
Shannon dan Indeks kemerataan Eveness terendah pada jarak 50 meter $\left(H^{\prime}=2,208 ; E=0,700\right)$. Indeks dominansi Simpson tertinggi pada jarak 0 meter $(\mathrm{D}=0,922)$ sedangkan indeks dominansi Simpson terendah pada jarak 50 meter $(\mathrm{D}=0,858)$. Masingmasing jarak memiliki nilai seperti yang tertera pada Tabel 4

Tabel 4. Indeks Keragaman Kupu-kupu pada Jarak yang Berbeda

\begin{tabular}{lccccc}
\multicolumn{1}{c}{ Indeks Ekologi } & 0 meter & 50 meter & 100 meter & 150 meter & 200 meter \\
\hline Keanekaragaman Shanno-Wiener (H') & 2.760 & 2.208 & 2.305 & 2.282 & 2.293 \\
Kenerataan Evenness (E) & 0,752 & 0,700 & 0,835 & 0,891 & 0,762 \\
Dominansi Simpson (D) & 0,922 & 0,858 & 0,886 & 0,885 & 0,882 \\
\hline
\end{tabular}

Indeks dominansi yang diperoleh menunjukkan bahwa dari kelimpahan individu dari spesies kupukupu terlihat tidak ada dominansi yang sangat menonjol. Hal ini sesuai dengan pernyataan Purwowidodo (2015), bahwa dominansi yang tidak menonjol dikarenakan kondisi habitat baik pada setiap stasiun memiliki ketersediaan sumber hidup seperti pakan, tanaman inang, tempat berlindung, dan berkembang biak yang cukup bervariasi dan/atau heterogen bagi kupu-kupu. Formula rumusan indeks dominansi dan indeks kemerataan sebenarnya memiliki korelasi yang bersifat negatif. Indeks dominansi berbanding terbalik dengan indeks kemerataan, artinya apabila indeks dominansi tinggi menunjukkan bahwa suatu habitat memiliki tingkat kemerataan atau keseragaman individu yang rendah, sebaliknya indeks dominansi yang rendah menunjukkan kecenderungan kelimpahan individu dari spesies kupu-kupu terdistribusi secara merata dalam suatu habitat. Pada jarak 0 meter didapatkan indeks dominasi paling tinggi dikuasai oleh spesies H. glaucippe (31 individu). Nilai indeks kemerataan kupu-kupu Cagar Alam Bantarbolang berdasarkan kriteria Pielou tergolong hampir merata $(\mathrm{E}=0,891)$. Apabila keseragaman mendekati nol berarti keseragaman antar spesies di dalam komunitas tergolong rendah dan sebaliknya keseragaman yang mendekati satu dapat dikatakan keseragaman antar spesies tergolong merata atau sama.Indeks keseragaman atau kemerataan ini dapat diartikan sebagai derajat kemerataan kelimpahan individu antar spesies (Pirzan et al., 2008).

Tabel 5. Matriks Similaritas antar Jarak di Cagar Alam Bantarbolang

\begin{tabular}{lccccc}
\hline Jarak & $0 \mathrm{~m}$ & $50 \mathrm{~m}$ & $100 \mathrm{~m}$ & $150 \mathrm{~m}$ & $200 \mathrm{~m}$ \\
\hline $0 \mathrm{~m}$ & $*$ & 42.6877 & 24.2424 & 15.7407 & 39,5437 \\
$50 \mathrm{~m}$ & $*$ & $*$ & 39.5339 & 42.2535 & 52.5424 \\
$100 \mathrm{~m}$ & $*$ & $*$ & $*$ & 32.6531 & 43.7500 \\
$150 \mathrm{~m}$ & $*$ & $*$ & $*$ & $*$ & 27.1605 \\
$200 \mathrm{~m}$ & $*$ & $*$ & $*$ & $*$ & $*$ \\
\hline
\end{tabular}

Similaritas (Kesamaan) Kupu-kupu antar jarak yang berbeda disajikan pada Tabel 5 . yang menyatakan bahwa nilai similaritas tertinggi ada pada jarak $50 \mathrm{~m}$ dan $200 \mathrm{~m}$ yaitu 52,5424 sedangkan nilai similaritas terendah ada pada jarak $0 \mathrm{~m}$ dan 150 m. Sehingga dapat diketahui nilai disimilaritas (ketidaksamaan) tertinggi yaitu pada jarak $0 \mathrm{~m}$ dan $150 \mathrm{~m}$ sedangkan nilai disimilaritas terendah yaitu pada jarak $50 \mathrm{~m}$ dan $200 \mathrm{~m}$. Dari hasil matriks similaritas tersebut maka diperoleh hasil nilai similaritas serta disimilaritas berbanding terbalik. Dendogram similaritas dapat dilihat pada Gambar 3. 


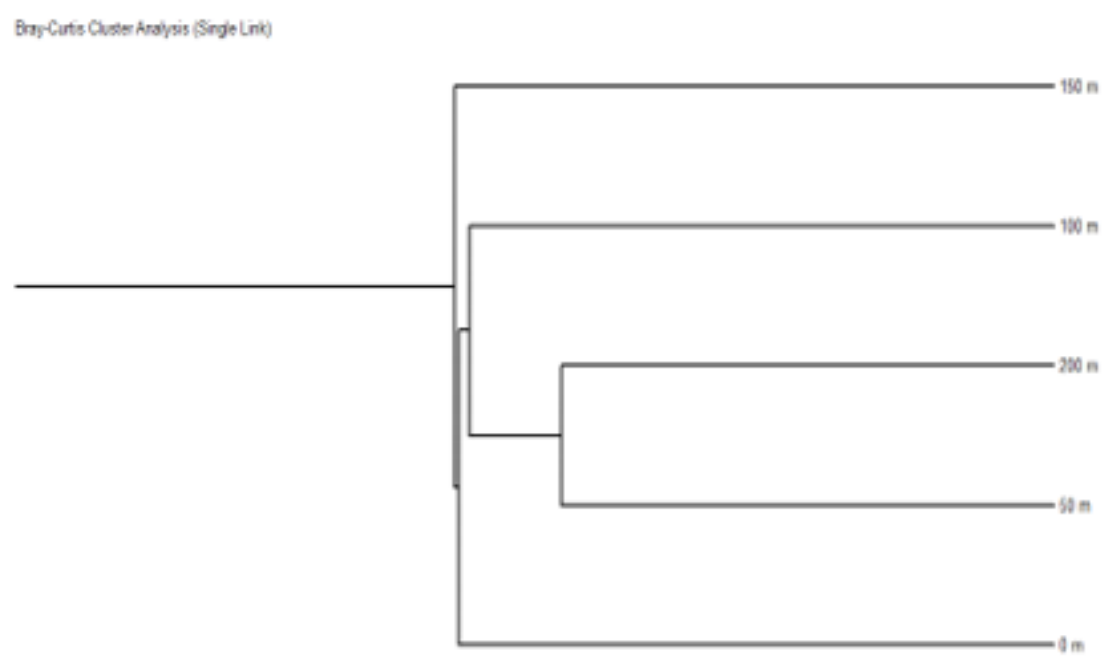

Gambar 3. Dendogram Similaritas dari Kupu-kupu pada Jarak yang Berbeda

Dendogram similaritas di atas menunjukkan bahwa kupu-kupu di Cagar Alam Bantarbolang yang paling mirip berada pada jarak 50 meter dan 200 meter. Kesamaan komposisi spesies pada jarak 50 meter dan 200 meter diduga karena memiliki kesamaan jenis tumbuhan pakan kupu-kupu. Hal ini sesuai dengan pernyataan Rahayuningsih et al. (2012) bahwa kesamaan kompoosisi spesies dipengaruhi oleh adanya pergerakan kupu-kupu yang cepat untuk berpindah habitat dan vegetasi antar habitat yang beragam sehingga mempengaruhi keberadaan jenis kupu-kupu. Vegetasi yang lebih beragam pada suatu habitat memiliki potensi ketersediaan pakan yang lebih baik dibandingkan dengan habitat lain dengan vegetasi yang kurang beragam. Perbedaan jumlah individu dan spesies yang didapatkan pada tiap lokasi dikarenakan perbedaan vegetasi dan keadaan lingkungan yang mempengaruhi keterse-diaanya suatu tumbuhan yang menjadi pakan larva dari spesies pada tiap individu tersebut. Kesamaan komposisi spesies disebabkan karena adanya kemiripan habitat dan kekhususan habitat secara langsung terkait dengan tanaman inang untuk kupu-kupu larva dan dewasa (Widhiono, 2015).

\section{SIMPULAN}

Berdasarkan pembahasan disimpulkan bahwa kenaekaragaman kupu-kupu tertinggi yaitu pada jarak $0 \mathrm{~m}\left(\mathrm{H}^{\prime}=2.760\right)$ dan terrendah pada jarak 50 $\mathrm{m}\left(\mathrm{H}^{\prime}=2.208\right)$. Keanekaragaman kupu-kupu di Cagar Alam Bantarbolang tergolong kategori sedang. Kelimpahan kupu-kupu paling tinggi pada jarak $0 \mathrm{~m}$ sebanyak 20 spesies dengan 192 individu dan kelimpahan kupu-kupu paling rendah pada jarak
$150 \mathrm{~m}$ sebanyak 11 spesies dengan 17 individu. Kelimpahan kupu-kupu di Cagar Alam Bantarbolang tergolong kategori rendah.

\section{DAFTAR REFERENSI}

Borror, D.J., Triplehorn, C.A. \& Johnson, N.F. 1992. Pengenalan Serangga. Yogyakarta: Gadjah Mada University Press.

Dendang, B. 2009. Keragaman kupu-kupu di Resort Selabintana Taman Nasional Gunung Gede Pangrango, Jawa Barat. Jurnal Penelitian Hutan dan Konservasi Alam, 6(1), pp. 25-36.

Dewi, B., Hamidah, A. \& Siburian, J. 2016. Keanekaragaman dan Kelimpahan Jenis Kupu-kupu (Lepidoptera; Rhopalocera) di Sekitar Kampus Pinang Masak Universitas Jambi. Jurnal Biospecies, 9(2), pp. 32-38.

Fauziyah, S., Maghfirah, F.F., Wulandari, A.D., Felayati, M., Sari, E.K.A., Winarni, A. \& AlYamini, T.A. 2017. Keanekaragaman KupuKupu di Kawasan Konservasi Petungsewu Wildlife Education Center, Malang, Jawa Timur. Jurnal Biodeversitas Indonesia, 3(2), pp. 252-257.

Febrita, E., Yustina \& Dahmania. 2014. Keanekaragaman Jenis Kupu-kupu (Subordo Rhopalocera) di Kawasan Wisata Hapanasan Rokan Hulu Sebagai Sumber Belajar pada Konsep Keanekaragaman Hayati. Jurnal Biogenesis, 10(2), pp. 49-58.

Jateng, B. 2004. Buku Informasi Kawasan Konservasi. Pemalang: BKSDA Jateng. 
Koneri, R. \& Saroyo. 2011. Keanekaragaman KupuKupu (Lepidoptera) pada Empat Tipe Habitat di Hutan Lindung Gunung Klabat, Sulawesi Utara. Jurnal Biosfera, 29(1) pp. 85-92.

Oqtafiana, R., Priyono, B. \& Rahayuningsih, M. 2013. Keanekaragaman Jenis Kupu-Kupu Superfamili Papilionoidae di Banyuwindu, Limbangan Kendal. Jurnal Biosaintifika, 5(1), pp. 58-64.

Panjaitanm, R. 2008. Distribusi kupu-kupu (Superfamili Papilionoidae: Lepidoptera) di Minyambou, Cagar Alam Pegunungan Arfak Manokwari, Papua Barat. Journal of Biology \& Biology Education, 7(1) pp. $11-16$.

Pirzan, Andi, M., \& Petrus, R. 2008. Hubungan Keragaman Fitoplankton dengan Kualitas Air di Pulau Baulung, Kabupaten Takalar, Sulawesi Selatan. Jurnal Biodiversitas, 9(3), pp. 217-221.

Priyono, B. \& Abdullah, M. 2013. Keanekaragaman Jenis Kupu-Kupu di Taman Kehati Unnes. Jurnal Biosaintifika, 5(2), pp. 100-105.

Purwowidodo. 2015. Studi Keanekaragaman Hayati Kupu-kupu (Sub ordo Rhopalocera) dan Peranan Ekologisnya di Area Hutan Lindung Kaki Gunung Prau Kabupaten Kendal Jawa Tengah. Skripsi. Semarang: Universitas Islam Negeri Walisongo.

Rahayuningsih, S. E., dan Adi, B. 2012. Kelimpahan dan Keanekaragaman Species Kupu-kupu (Lepidoptera: Rhopalocera) pada Berbagai Tipe Habitat di Hutan Kota Muhammad Sabki Kota Jambi. Jurnal Biospecies, 5(2), pp. 40-48.
Setiowati, T., \& Furqonita, D. 2007. Biologi Interaktif untuk SMA/MA. Jakarta: Azka Press.

Sharm, G., dan Joshi, P.C. 2009. Diversity of Butterflies (Lepidoptera: Insecta) from Dholbaha dam (Distt.Hoshiarpur) in Punjab Shivalik, India. Biological Forum-An International Journal. 1(2): 11-14.

Suharto, Wagiyana \& Zulkarnain R. 2005. Survei Ku-pu-Kupu (Rhopalocera: Lepidoptera) di Hutan Ireng-Ireng Taman Nasional Bromo Tengger Semeru. Jurnal Ilmu Dasar. 6: 1-5.

Sutra, N.S.M., Dahelmi, \& Siti, S. 2012. Species Kupu-kupu (Rhopalocera) Di Tanjung Balai Karimun Kabupaten Karimun, Kepulauan Riau. Jurnal Biologi Universitas Andalas. 1(1): 35-44.

Widhiono, I. 2014. Keragaman dan Kelimpahan Kupu-Kupu Endemic Jawa (Lepidoptera: Rhopalocera) di Hutan Gunung Slamet Jawa Tengah. Jurnal Biospecies, 7(2), pp. 59-67.

Widhiono, I. 2015. Diversity of Butterflies in Four Different Forest Types in Mount Slamet, Central Java, Indonesia. Journal Biodiversitas, 16(2), pp. 196-204. 